Artikel Penelitian

\title{
Substitusi Terigu dengan Pati Sorgum Terfermentasi pada Pembuatan Roti Tawar: Studi Suhu Pemanggangan
}

\section{Fermented Sorghum Starch as Wheat Flour Substitution in Bread Production: Roasting Temperature Effect}

Kristinah Haryani*, Hargono, Noer Abyor Handayani, Putri Ramadani, Dikie Rezekia

Fakultas Teknik, Departemen Teknik Kimia, Universitas Diponegoro, Semarang

*Korespondensi dengan penulis (krisyani_83@yahoo.co.id)

Artikel ini dikirim pada tanggal 19 Februari 2017 dan dinyatakan diterima tanggal 2 Juni 2017. Artikel ini juga dipublikasi secara online melalui www.jatp.ift.or.id. Hak cipta dilindungi undang-undang. Dilarang diperbanyak untuk tujuan komersial.

Diproduksi oleh Indonesian Food Technologists® @ 2017

\begin{abstract}
Abstrak
Sorgum memiliki kandungan nutrisi yang tidak kalah tinggi jika dibandingkan dengan tanaman serealia lain seperti gandum, jagung, atau padi. Namun sorgum memiliki beberapa kelemahan jika dibandingkan dengan gandum. Protein dalam biji sorgum mengandung kafirin, yang cenderung membentuk ikatan disulfida yang bersifat hidrofobik, yang menyebabkan tepung sorgum sulit mengembang ketika difermentasi menjadi roti dan keadaan ini diperparah ketika sorgum dimasak. Hal ini juga menyebabkan protein dan pati sorgum menjadi sulit dicerna. Salah satu upaya untuk meningkatkan kualitas serta daya cerna dari roti sorgum yaitu dengan cara fermentasi. Penelitian ini dilakukan untuk mengetahui suhu pemanggangan terhadap karakteristik roti tawar. Ada dua macam roti tawar yang diteliti yang pertama dibuat dari tepung terigu dicampur dengan pati sorghum merah terfermentasi sebanyak $60 \%$, yang kedua tepung terigu dicampur pati sorghum putih terfermentasi sebanyak $40 \%$. Dari kedua komposisi tersebut dilakukan studi pada suhu pemanggangan $180^{\circ} \mathrm{C}, 190^{\circ} \mathrm{C}, 200^{\circ} \mathrm{C}, 210^{\circ} \mathrm{C}$ dan $220^{\circ} \mathrm{C}$. Dari hasil uji organoleptik terhadap rasa, warna dan aroma diperoleh roti yang dipanggang pada suhu $200^{\circ} \mathrm{C}$ yang paling disukai.
\end{abstract}

Kata kunci: roti tawar, pati sorghum, fermentasi, bakteri asam laktat, suhu pemanggangan

\section{Abstract}

Sorghum has no less nutrient content when compared to other cereal crops such as wheat, corn, or rice. However, sorghum has some disadvantages when compared to wheat. Protein in sorghum grain contains kafirin, which tend to form disulfide bonds that are hydrophobich. Kafirin in sorghum causes difficulties in sorghum flour to expand during bread fermentation and this situation being worsen when sorghum is cooked. It also causes the protein and starch sorghum becomes difficult to digest. One effort to improve the quality and digestibility of sorghum bread is through fermentation fermentation using mixed culture of lactid acid bacteria because of this mixed culture has successfully modified cassava flour. This study aims to assess the best oven temperature to produce bread that is acceptable. There are two kinds of bread studied. The first made of flour mixed with fermented red sorghum starch as much as $60 \%$. The second is flour mixed with $40 \%$ of fermented white sorghum starch. Both of the composition studies carried out at roasting temperature $180^{\circ} \mathrm{C}, 190^{\circ} \mathrm{C}, 200^{\circ} \mathrm{C}, 210^{\circ} \mathrm{C}$ and $220^{\circ} \mathrm{C}$. The results of organoleptic test for taste, color and odor showed that the bread baked at a temperature of $200^{\circ} \mathrm{C}$ was most preferred.

Keywords: bread, sorghum starch, fermentation, lactic acid bacteria, roasting temperature

\section{Pendahuluan}

Masyarakat Indonesia saat ini banyak yang mengonsumsi roti sebagai makanan penghasil energi. Semakin tinggi tingkat kesibukan khususnya di kotakota besar menyebabkan kebutuhan akan roti semakin meningkat karena roti merupakan makanan yang praktis, tidak memerlukan persiapan yang lama, dan mengandung zat gizi yang baik. Umumnya roti dibuat dengan bahan baku tepung terigu dimana gandum sebagai penghasil tepung terigu belum dapat ditanam di Indonesia sehingga mengharuskan adanya impor dari negara penghasil gandum (Lestari, 2010). Salah satu alternatif pemecahan masalah tersebut adalah pemanfaatan bahan baku lokal seperti sorgum sebagai bahan pengganti atau substitusi tepung terigu.

Sorgum memiliki kandungan yang hampir sama dengan gandum sebagai bahan baku tepung terigu. Sorgum mengandung karbohidrat $83 \%$, lemak 3,50\%, dan protein $10 \%$ (basis kering). Namun di sisi lain, sorgum memiliki kandungan tanin yang menyebabkan rasa pahit yang kurang disukai sehingga pemanfatan sorgum di Indonesia masih terbatas. Disamping itu, sorgum juga mengandung kompleks protein yang disebut kafirin, yang menyebabkan struktur sorgum menjadi kaku sehingga sulit dicerna (Wong et al ., 2010). Untuk menghasilkan roti dengan kualitas yang hampir sama dengan roti gandum, maka perlu dilakukan fermentasi pati sorgum dengan penambahan campuran bakteri asam laktat kultur campuran. Mikroorganisme yang digunakan merupakan kultur campuran, terutama terdiri dari Lactobacillus plantarum, Lactobcillus casei dan Lactobacillus bulgaricus serta yeast Saccharomyces cerevisiae. Pada penelitian ini, akan dikaji pengaruh suhu pemanggangan pada pembuatan roti tawar dengan substitusi pati sorghum terfermentasi.

\section{Materi dan Metode \\ Materi}

Bahan-bahan yang digunakan dalam penelitian ini adalah biji sorgum merah dan putih (Diperoleh dari Pasar Pracimantoro, Wonogiri), Kultur campuran 
bakteri asam laktat (Diperoleh dari Mitra Bisnis UKM Jeruk Legi, Banguntapan, Bantul), aquadest, tepung terigu, kuning telur ayam, ragi roti, garam, gula, mentega putih/Shortening. Sedangkan peralatan yang digunakan adalah autoclave, gelas beaker, gelas ukur, pipet volume, pipet tetes, inkubator, loyang, oven, dan mixer.serta tekstur analyzer,untuk uji tekstur (hardness) pada roti.

\section{Metode}

Penelitian ini terdiri dari 2 proses utama, yang pertama yaitu proses pembuatan pati sorgum terfermentasi. Pati sorgum difermentasi dengan cara melarutkan pati sorgum dalam air dengan perbandingan pati sorgum : air adalah $1: 1.25$ dan diinokulasikan kultur campuran bakteri asam laktat, aduk sampai rata. Setelah itu, campuran tersebut ditutup dengan alumunium foil dan dimasukkan inkubator dengan suhu fermentasi $37^{\circ} \mathrm{C}$ selama 24 jam. Pati sorgum hasil fermentasi dipindahkan ke dalam loyang kemudian dikeringkan dalam oven dengan suhu $70^{\circ} \mathrm{C}$. Untuk mendapatkan hasil pati yang seragam, pati sorgum yang telah dikeringkan dihancurkan lagi dengan mixer lalu diayak.

Kedua proses pembuatan roti tawar menggunakan pati sorgum terfermentasi . Hal pertama yang dilakukan adalah menyiapkan alat dan bahan yang akan digunakan pada pembuatan roti. Kemudian menimbang masing-masing bahan sesuai komposisinya. Selanjutnya semua bahan kering yaitu ragi roti, tepung, dan gula, diaduk dan aduk sampai rata. Setelah itu masukkan mentega putih (shortening), kuning telor, air dingin, dan garam lalu diaduk hingga kalis. Adonan dibiarkan selama 15-30 menit (suhu ruang). Adonan dibagi menjadi beberapa bagian kemudian dipipihkan adonan, dibuang gasnya, digulung dan ditutup rapat adonan tersebut agar tidak terbuka waktu pemanggangan. Adonan yang telah dipipih dibiarkan selama 15-30 menit hingga mengembang. Adonan dimasukkan ke dalam oven dengan suhu pemanggangan $180^{\circ} \mathrm{C}, 190^{\circ} \mathrm{C}, 200^{\circ} \mathrm{C}, 210^{\circ} \mathrm{C}, 220^{\circ} \mathrm{C}$, tunggu sampai matang. Roti yang sudah matang dikeluarkan dari cetakan/loyang sesegera mungkin, kemudian didinginkan roti pada suhu ruang.Setelah itu, roti dipotong pada suhu $30-32^{\circ} \mathrm{C}$.

\section{Uji Sensori Roti Tawar}

Uji sensori yang dilakukan adalah uji rating hedonik terhadap lima formula oleh 25 panelis tidak terlatih. Parameter mutu yang diuji meliputi warna, rasa, aroma dan tekstur. Pemberian skor pada uji rating hedonik menggunakan sistem skala kategori yaitu sangat tidak suka (1), tidak suka (2), agak tidak suka (3), netral (4), agak suka (5), suka (6), dan sangat suka (7). Formula yang diasumsikan masih diterima oleh panelis yaitu formula yang mepunyai nilai kesukaan minimal netral (4) untuk semua parameter mutu yang diuji.

\section{Hasil dan Pembahasan}

Pemanggangan merupakan salah satu proses pengolahan pangan yang menggunakan media panas dalam upaya pemasakan dan pengeringan bahan pangan. Pemangganan juga memberikan efek pengawetan karena terjadi inaktivasi mikroba dan enzim serta penurunan Aw (aktivitas air). Proses pemanggangan menyebabkan perubahan warna, tekstur, aroma dan rasa dari bahan. Berdasarkan Grafik 1. menunjukkan hasil roti tawar sorgum merah dengan penambahan $3 \mathrm{~g}$ yeast pada berbagai suhu pemanggangan. Sedangkan pada Grafik 2. menunjukkan hasil roti tawar sorgum putih pada penambahan $2 \mathrm{~g}$ yeast pada berbagai suhu pemanggangan.

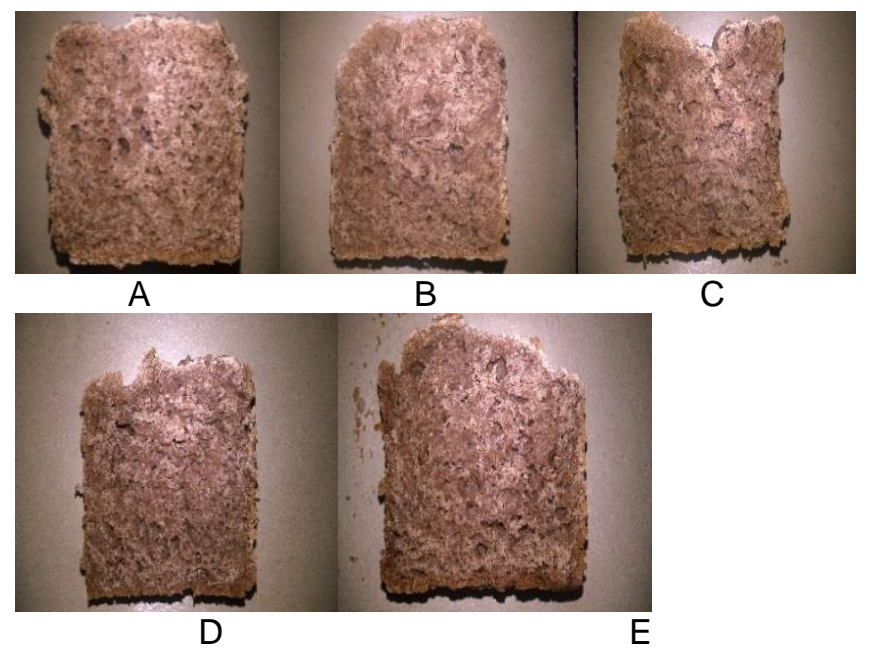

Grafik 1. Roti tawar sorgum merah $60 \%$ dengan penambahan yeast $3 \mathrm{~g}$ dengan berbagai suhu pemanggangan

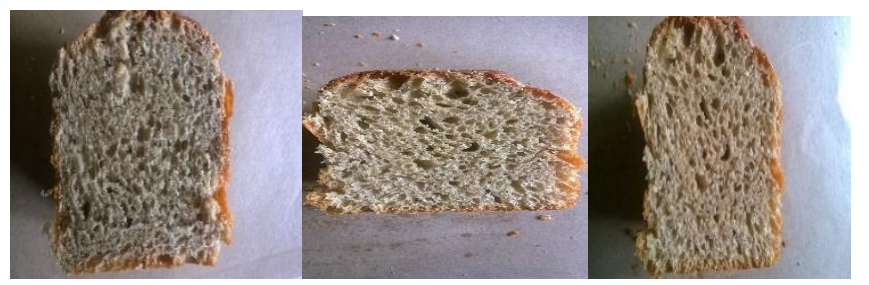

A B

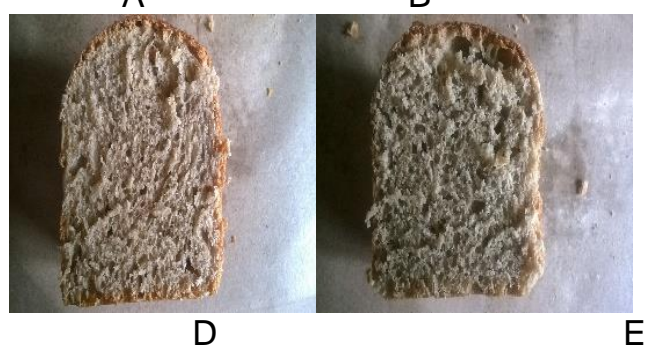

Grafik 2. Roti tawar sorgum putih $40 \%$ dengan penambahan yeast $2 \mathrm{~g}$ dengan berbagai suhu pemanggangan

Ket: A: suhu $180^{\circ} \mathrm{C}$, B: suhu $190^{\circ} \mathrm{C}$, C: suhu $200^{\circ} \mathrm{C}$, D: suhu $210^{\circ} \mathrm{C}, \mathrm{E}: 220^{\circ} \mathrm{C}$

\section{Pengaruh Suhu Pemanggangan terhadap Warna}

Hasil uji rating hedonik terhadap warna dari variasi suhu pemanggangan roti tawar yang berbedabeda pada setiap adonan roti tawar sorgum merah dan adonan roti tawar sorgum putih (Grafik 1). Pemanggangan merupakan aspek yang kritis dari urutan proses untuk menghasilkan roti yang berkualitas tinggi. Pemangganan yang terlalu lama dapat menyebabkan kekerasan dan penampakan yang tidak baik (Farikha, 2012). Pembentukan warna cokelat pada permukaan roti setelah dipanggang adalah hasil dari reaksi Maillard. Reaksi Maillard adalah reaksi yang terjadi antara gula pereduksi (terutama a-D-glukosa) dengan gugus amin bebas dari asam amino, bagian 
protein atau senyawa lain yang mengandung gugus amin. Reaksi Maillard berlangsung dalam beberapa tahap, yaitu tahap kondensasi, tahap penyusunan kembali (Amadori rearrangement) dan tahap polimerisasi.Tahap kondensasi merupakan tahap awal (inisiasi) yang melibatkan reaksi antara gula aldosa atau ketosa dengan gugus amin. Pada tahap Amadori rearrangement, $\mathrm{N}$-substitued glycosylamin akan membentuk senyawa lain.

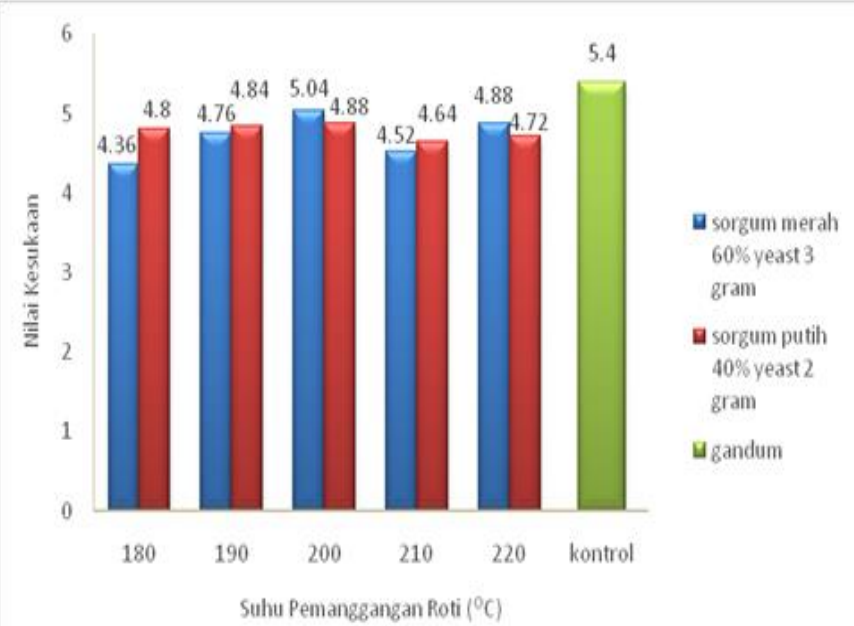

Grafik 1. Rating Hedonik terhadap Warna Roti Tawar Sorgum Merah dan Roti Tawar Sorgum Putih pada Berbagai Suhu Pemanggangan

\section{Pengaruh Suhu Pemanggangan terhadap Aroma}

Hasil uji rating hedonik terhadap aroma dari variasi suhu pemanggangan roti tawar yang berbedabeda pada setiap adonan roti tawar sorgum merah dan adonan roti tawar sorgum putih (Grafik 2). Perubahan aroma hingga tercium bau khas roti yang kuat disebabkan oleh reaksi-reaksi yang berlangsung saat pemanggangan. Aroma khas produk panggang dihasilkan oleh beberapa reaksi diantaranya reaksi Maillard dan karamelisasi (Prabawati, 2014). Tipe aroma tergantung dari asam amino, lemak, gula, dan suhu. Suhu pemanggangan yang terlalu rendah akan menyebabkan aroma khas roti menjadi kurang kuat, dan suhu pemanggangan yang terlalu tinggi akan menyebabkan aroma menjadi bau hangus atau gosong akibat dari proses Maillard dan karamelisasi yang berkelanjutan. Pada penelitian ini suhu yang menghasilkan produk dengan aroma terbaik adalah roti tawar yang dipanggang pada suhu $200^{\circ} \mathrm{C}$.

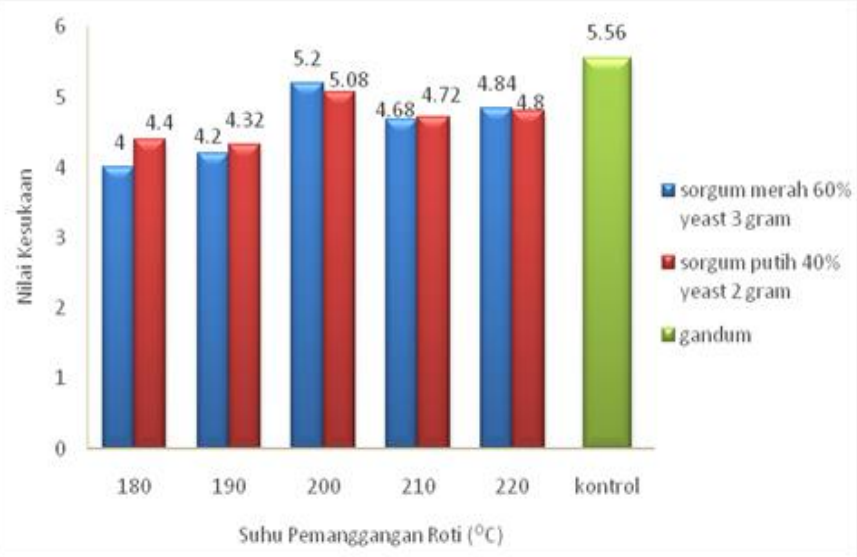

Grafik 2. Rating Hedonik terhadap Aroma Roti Tawar Sorgum Merah dan Roti Tawar Sorgum Putih pada Berbagai Suhu Pemanggangan
Pengaruh Suhu Pemanggangan terhadapTekstur

Hasil uji rating hedonik terhadap tekstur dari variasi suhu pemanggangan roti tawar yang berbedabeda pada setiap adonan roti tawar sorgum merah dan adonan roti tawar sorgum putih (Grafik 3). Menurut Prabawati (2014), perubahan tekstur pada proses pemanggangan roti disebabkan oleh panas yang dialirkan di dalam oven. Sebelum dimasukkan ke dalam oven, adonan roti mengandung kadar air. Dengan adanya panas dari oven, air di dekat permukaan akan menguap. Selanjutnya uap air tersebut akan berpindah ke fase gasnya melalui proses difusi ke dalam produk atau bahkan ke luar melalui sel permukaan produk. Dengan adanya panas dari permukaan dan menuju ke dalam produk,maka uap air yang bertemu dengan uap air yang lebih dingin di pusat produk akan mengalami kondensasi sampai jumlah tersebut berkurang karena adanya pengaruh panas. Pada proses pemanggangan kandungan air akan menurun yang disebabkan oleh proses perpindahan masa air dari tengah produk ke permukaan. Sedangkan pada permukaan (crust), kandungan airnya sangat cepat mengalami penguapan. Sehingga pada saat selesai pemanggangan, kadar air dari bahan sudah banyak yang hilang dan membentuk tekstur remah roti yang kokoh.

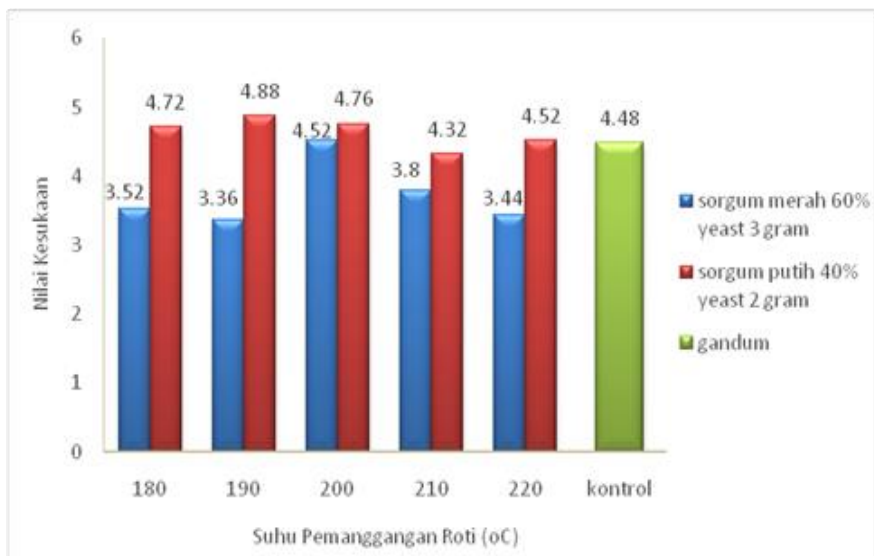

Grafik 3. Grafik Rating Hedonik terhadap Tekstur Roti Tawar Sorgum Merah dan Roti Tawar Sorgum Putih pada Berbagai Suhu Pemanggangan

Dengan semakin tinggi suhu oven maka laju penguapan air akan lebih cepat, begitu juga sebaliknya. Ferona (2012), menyebutkan bahwa penyebab roti tidak mengembang dan keras adalah suhu oven yang rendah. Suhu oven yang lebih rendah dari yang semestinya maka waktu pembakaran akan menjadi lebih lama sehingga hasilnya akan keras. Suhu oven yang disarankan untuk roti tawar berkisar antara 200$210^{\circ} \mathrm{C}$ dengan waktu pembakaran 20-35 menit.Sedangkan suhu pamangganan yang terlalu tinggi dapat menyebabkan tekstur menjadi jelek dan rapuh (crumbly).

\section{Pengaruh Suhu Pemanggangan terhadap Rasa}

Hasil uji rating hedonik terhadap rasa dari variasi suhu pemanggangan roti tawar yang berbeda-beda pada setiap adonan roti tawar sorgum merah dan adonan roti tawar sorgum putih (Grafik 4). Pemanggangan merupakan proses pemanasan kering 
menggunakan oven atau media sejenisnya yang dapat mengakibatkan perubahan citarasa, kenampakan, dan komposisi kimia bahan pangan sehingga produknya dapat diterima oleh konsumen (Prabawati, 2014).

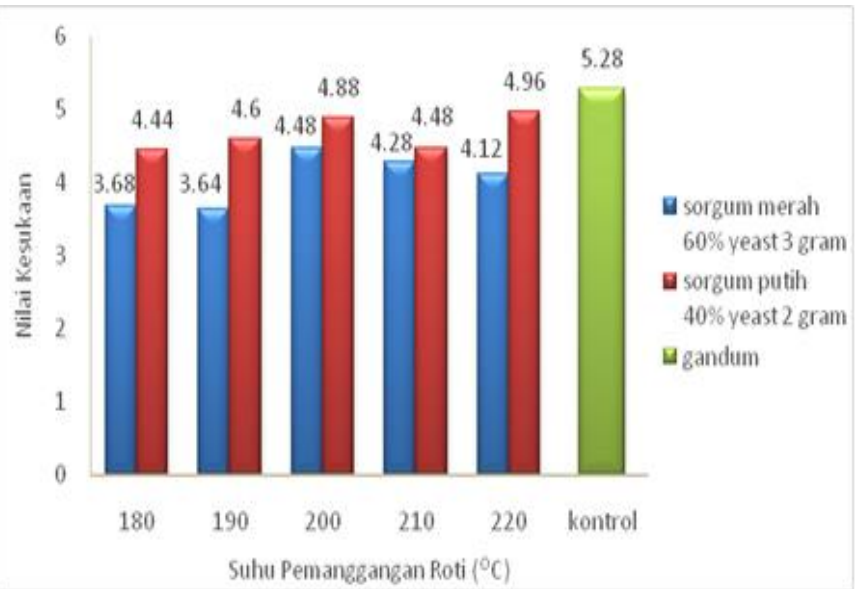

Grafik 4. Rating Hedonik terhadap Rasa Roti Tawar Sorgum Merah dan Roti Tawar Sorgum Putih pada berbagai Suhu Pemanggangan.

Reaksi Maillard yang terjadi selama proses pemanggangan menghasilkan rasa dan aroma yang khas. Reaksi Maillard terjadi antara gugus karbonil yang relatif dari senyawa gula bereaksi dengan gugus amino nukleophilik, hasilnya berupa campuran kompleks molekul yang bertanggung jawab untuk membentuk rasa dan aroma (Krisnawati, 2014). Selain itu, rasa dari roti tawar yang dihasilkan juga bergantung pada bahan-bahan lain yang ditambahkan untuk membuat adonan roti, seperti yeast, gula, garam, telur, dan lemak yang masing-masing memberikan rasa yang berbeda-beda sehingga memberikan rasa khas roti (Latipah, 2016).

Suhu saat pemangganan roti juga tidak boleh terlalu tinggi ataupun terlalu rendah karena dapat mempengaruhi rasa yang dihasilkan produk (roti). Dengan memberikan suhu yang optimal pada proses pemanggangan roti $\left(200-210^{\circ} \mathrm{C}\right)$ maka akan diperoleh rasa khas roti yang baik (enak).

\section{Kesimpulan}

Berdasarkan sifat sensoris, sifat fisik dan sifat kimia dari produk roti tawar yang dihasilkan, sorgum merah dan sorgum putih memiliki potensi sebagai bahan pengganti tepung terigu pada pembuatan roti tawar sampai dengan $60 \%$ dalam $100 \mathrm{gr}$ bahan.

\section{Daftar Pustaka}

Farikha, D. 2012. Pengaruh Pemanggangan terhadap Kandungan Gizi Pada Tepung. Skripsi. Universitas Diponegoro, Semarang.

Ferona. 2012. Tips untuk Proses Pembuatan Roti. http://www.cakefever.com (Diakses pada 11 November 2015)

Krisnawati, R. 2014. Pengaruh Substitusi Puree Ubi Jalar Ungu (Ipomea Batatas) Terhadap Mutu Organoleptik Roti Tawar. Jurnal Tata Boga. 3(1)

Latipah, N. 2015. Proses Pembuatan Roti.http://www.academia.edu (Diakses pada 12 November 2015)
Lestari, D. P. 2010.Karakterisasi fisikokimia tepung sorgum fermentasi dan aplikasinya sebagai bahan substitusi roti tawar, 1-76.

Prabawati, N. 2014. Teknologi Pengolahan Pangan I : Pemanggangan. Universitas Jenderal Soedirman. Purwokerto.

Wong, J. H., Marx, D. B., Wilson, J. D., Buchanan, B. B., Lemaux, P. G., Pedersen, J. F. (2010). Principal component analysis and biochemical characterization of protein and starch reveal primary targets for improving sorghum grain. Plant Science, 179(6), 598-611. 